\title{
Phisicochemical, sensory, and microbiological evaluation and development of symbiotic fermented drink
}

Mônica de Lucena Lira Aguiar DIAS ${ }^{1}$, Silvana Magalhães SALGADO ${ }^{1 \star}$, Nonete Barbosa GUERRA ${ }^{1}$, Alda Verônica Souza LIVERA ${ }^{1}$, Samara Alvachian Cardoso ANDRADE ${ }^{1}$, Graciliane Nobre da Cruz XIMENES ${ }^{1}$

\begin{abstract}
The goal of this study was to develop a symbiotic lacteous drink, evaluate its physicochemical and sensory characteristics, and verify the viability of Lactobacillus acidophilus in the drink. The milk serum-based drink consisted of $50 \%$ milk serum containing $10 \%$ saccharose, $25 \%$ powdered milk, $15 \%$ yacon pulp, and cultures of Lactobacillus acidophilus-La 5E and Bifidobacterium bifidum BB12. It was stored for up to 21 days under refrigeration. The milk serum-based drink was analyzed for protein, ether extract, total dietary fiber, total frutans, carbohydrate content, color, $\mathrm{pH}$, acidity, and contamination by coliforms, and Salmonella sp. Coliforms and Salmonella sp were not detected, and L. acidophilus and B. bifidum provided satisfactory probiotic counts up to 21 days of storage under refrigeration. Lactobacillus acidophilus resistance to gastric acids and bile salts was detected only up to seven days of storage when evaluated in vitro. Sensory analysis and purchase viability were evaluated by consumers at $0,7,14$, and 21 days of storage. Based on the analytical results and consumer evaluation, the drink was acceptable up to seven days of storage.
\end{abstract}

Keywords: probiotics; yacon; milk drink.

\section{Introduction}

In the last decades, the food industry has incorporated new technologies that allow utilization of residues resulting from food production. The cheese industry sector is a major sector of the food industry and generates a large volume of milk serum as the residue from cheese production. Several studies have been carried out aiming at finding a better use for the milk whey reducing pollution caused by its disposal, which causes environmental problem due to its high content of organic materials and high biological demand of oxygen necessary for lactose deterioration (ZAVAREZE; MORAES; SALAS-MELLADO, 2010).

Whey contains significant amounts of proteins and lactose, which have high nutritional value (ANTUNES et al., 2007). The use of the Milk serum to produce beverages has been studied by several researchers such as Antunes et al. (2007) and Bürger et al. (2011), who investigated methods to reduce the costs of its production aiming at obtaining a product with enhanced characteristics and chemical composition and diversified use.

Fermented drinks are among the most consumed products in Brazil. Therefore, the use of milk serum in the production of lacteous drinks may result in improved or new products (ANTUNES et al., 2007; SAAD; CRUZ; FARIA, 2011).

Another industry trend is the production of yogurt and fermented milk drinks, which, in addition to relevant consumers' acceptance, have very good nutritional value and are a potential vehicle for probiotic intake (ANTUNES et al., 2007; HAUG; HOSTMARK; HARSTAD, 2007).
Probiotics may provide nutritional benefits, enhance product flavor, and reduce acidification during storage (BURITI; SAAD, 2007). Probiotic bacteria, particularly bifidobacteria and lactobacilli, are normal inhabitants of the human intestinal tract and are, therefore, the most used bacteria in probiotic food production (BURITI; SAAD, 2007; BURITI et al., 2007). The minimum daily load of cultured probiotics that is considered therapeutic is $10^{8}-10^{9} \mathrm{CFU}$, which corresponds to $100 \mathrm{~g}$ of product. However, in order to have therapeutic merit, microorganism concentrations of between $10^{6}$ and $10^{7} \mathrm{CFU} / \mathrm{g}$ must remain constant during storage (CRUZ et al., 2010).

The combination of bioactive carbohydrates and probiotic microorganisms is currently used in the dairy industry; the consumption of such products is increasing because consumers are becoming more aware of the significance of health issues. The study of products that contribute to health and wellbeing of consumers is a priority worldwide (FIGUEIROAGONZALEZ; CRUZ-GUERRERO; QUIJANO, 2011). Yacon is an Andean species from the Asteracea family that has been studied in the recent decades because it is a source of bioactive compounds that are important to human health. Its most important components are water and carbohydrate, which are mainly stored as fructooligosaccharides (FOS) and other free sugars (PADILHA et al., 2009; SWANSON et al., 2002). Other studies have demonstrated the potential use of yacon fructans combined with probiotic cultures in the development of yogurt (OJANSIVU; FERREIRA; IMINEN, 2011).

Received 9/10/2013

Accepted 11/2/2013 (006192)

${ }^{1}$ Laboratório de Experimentação e Análises de Alimentos - LEAAL, Departamento de Nutrição, Universidade Federal de Pernambuco - UFPE, Rua Prof. Moraes Rego, s/n, Cidade Universitária, CEP 50670-901, Recife, PE, Brasil, e-mail: silvanasalgado@ufpe.br; leaalnutricao@ufpe.br

${ }^{*}$ Corresponding author 
The goal of this study was to develop a symbiotic lacteous drink, evaluate its physicochemical and sensory characteristics, and verify the viability of Lactobacillus acidophilus in the drink during storage.

\section{Materials and methods}

\subsection{Drink preparation}

The fermented drink was prepared with pasteurized homogenized milk and coagulant (Rennin) Há-La by Christian Hansen at the proportion of $1 \mathrm{ml}$ of rennin in $5 \mathrm{ml}$ of distilled water. The raw materials used in the drink formulation were pasteurized milk serum (50\%), saccharose (10\%), re-hydrated whole milk powder (25\%), and yacon pulp (15\%). The inoculants were prepared from lyophilized bacteria cultures of the probiotic microorganisms Bifidobacterium $\mathrm{Bb} 12$ and Lactobacillus acidophilus LA-5 (Christian Hansen). The stock culture was prepared with $1 \mathrm{~g}$ of each culture (containing $1.0 \times 10^{6}$ $\mathrm{CFU} \mathrm{g^{-1 }}$ ) inoculated in $1 \mathrm{~L}$ of pasteurized cow milk.

The milk fermentation process was performed at controlled temperature and $\mathrm{pH}\left(36^{\circ} \mathrm{C}\right.$ and $\left.\mathrm{pH} 5.0\right)$; the $\mathrm{pH}$ was monitored at $0,30,50$, and 180 minutes. The drink was stored in aliquots in screw-capped clear glass vials at $6^{\circ} \mathrm{C}\left(+1{ }^{\circ} \mathrm{C}\right)$ for up to 21 days.

\subsection{Physicochemical and microbiological assays}

Triplicate samples were used for the evaluation of $\mathrm{pH}$ and the following physicochemical parameters: acidity, by titulometria; protein, by the Kjedahl method; ether extract, by Soxlhet; ash, by gravimetric incineration; total dietary fiber content, by enzymatic gravimetric method; and fructans by enzyme determination adapted by Quemener, Thibault and Coussement (1994, 1997) (ASSOCIATION..., 2002). Carbohydrates were calculated by difference.

The presence of coliforms at $45^{\circ} \mathrm{C}$ and Salmonella spp $/ 25 \mathrm{~mL}$ was determined to evaluate the hygienic-sanitary conditions of the process (SILVA; JUNQUEIRA; SILVEIRA, 2010).

The color of the fermented drink was evaluated on days $1,7,14$, and 21 of storage using the CIELAB system based on three established chromatic coordinates: parameters $\mathrm{L}^{*}, \mathrm{a}^{*}$, and $\mathrm{b}^{*}$ and the measurement of total color difference $(\Delta \mathrm{E})$ (COMMISSION..., 2004).

The counts of Lactobacillus acidophilus LA-5 in $25 \mathrm{~mL}$ of the drink was based on the methods described in Cardarelli et al. (2008). The drink was dissolved in $0.1 \%$ sterile peptonated water. Aliquots of $1 \mathrm{~mL}$ were transferred to Petri dishes in duplicates with subsequent addition of MRS agar (Oxoid Ltda. Basingstoke, United Kingdom) modified by substituting maltose for glucose as described by the International Dairy Federation (1995). These plates were incubated anaerobically for 48 hours at $37^{\circ} \mathrm{C}( \pm 1)$ (CARDARELLI et al., 2008).

The counts of Bifidobacterium bifidum BB12 was determined in $25 \mathrm{ml}$ of drink dissolved in $0.1 \%$ sterile peptonated water. Aliquots of $1 \mathrm{~mL}$ of this dilution were transferred to two test tubes containing $9 \mathrm{~mL}$ of $0.1 \%$ sterile peptonated water solution.
In order to determine the counts of bifidobacteria $(1 \mathrm{~mL})$, they were deep seeded in agar (MRS Agar, Oxoid) supplemented with sodium propionate $(0.3 \% \mathrm{~m} / \mathrm{v})$ and lithium chloride $(0.2 \%$ $\mathrm{m} / \mathrm{v})$. These plates were incubated for 72 hours under anaerobic conditions at $37^{\circ} \mathrm{C} \pm 1{ }^{\circ} \mathrm{C}$ and the microorganisms were then counted (CARDARELLI et al., 2008). The organisms were identified in five colonies using catalase test and Gram stain. Microorganism count was expressed in terms of CFU/mL.

The Lactobacillus acidophilus resistance to gastric and enteric fluids was evaluated according to Liserre, Ré and Frango (2007). Total assay time was 6 hours. The aliquots containing the simulated gastric and enteric juices were evaluated at 30 minutes, 2,4 , and 6 hours from the beginning of the in vitro assay. Each assay was performed in duplicate. One $\mathrm{mL}$ of these aliquots was plated on modified MRS agar and incubated in a Gaspak jar (Anaerogen Anaerobiosis System, Oxoid) for Lactobacillus acidophilus viability counts after 48 hours of incubation at $37^{\circ} \mathrm{C}$ $(+1)$. The results were expressed as CFU/mL.

\subsection{Sensory analysis}

The acceptance tests were performed using a 9-point hedonic scale anchored with: $1=$ dislike extremely, $5=$ neither like nor dislike, and $9=$ like extremely (INTERNATIONAL..., 1995); and purchase intention was anchored with $1=$ buy, 2 = would not buy, 3 = maybe would buy. Both tests were performed at $0,7,14$, and 21 days of storage.

These tests were approved by the CEP/CCS/UFPE (\#574/2011 - registry of SISNEP FR-421831 - CAAE 0170.0.172.000-11), and a written consent was signed by all participants.

Each test at each different time of analysis was performed with 50 untrained tasters, $12.6 \%$ male and $87.4 \%$ female and average age of 22 (for females) and 21 years old (for males), recruited randomly from inside and outside of the Federal University of Pernambuco (Brazil).

The selection criterion was the nonexistence of allergic reactions to milk and regular consumption of dairy products, especially yoghurt and fermented milks. The samples $(50 \mathrm{ml})$ were served at refrigeration temperature in clear plastic cups. All sensory analyses were carried out in individual booths with controlled temperature $\left(20^{\circ} \mathrm{C}\right)$ under incandescent lighting.

\subsection{Statistic analysis}

The data were analyzed by ANOVA and the Duncan test at the 5\% significance level using the Statistic for Windows 6.0 software for comparison between the means (STATSOFT, 2004).

\section{Results and discussion}

\subsection{Physicochemical assays}

The protein values identified in the fermented drink (Table 1) were within the acceptable range established by the Brazilian legislation, $1.7 \mathrm{~g} / 100 \mathrm{~g}$ of protein of milk origin (BRASIL, 2005). The lipid content of the drink was $0.5 \mathrm{~g} / 100 \mathrm{~mL}$, 
and therefore it was considered as skimmed milk according to the Brazilian legislation (BRASIL, 2000), which establishes a maximum fat content of $0.5 \mathrm{~g} / 100 \mathrm{~g}$ for products of this category. The ash content was less than $1 \%$, similar to the values found by Thamer and Penna (2006).

In the last decades, fructans have been added to processed foods through ingredients such as the extensively studied yacon, which has high concentration of this carbohydrate (OJANSIVU; FERREIRA; IMINEN, 2011). The ripening stage of yacon affects the characteristics of the fructans content; high molecular weight carbohydrates are hydrolyzed into smaller molecules before becoming an energy source for the respiration and transpiration processes (GRAEFE et al., 2004). The fructan content was $68.57 \%$ of the total dietary fiber, demonstrating the potential of yacon for the development of new functional products. The alleged health promotion according to the Brazilian legislation (BRASIL, 1999) is of $1.5 \mathrm{~g} /$ portion of fiber of per serving of the product.

Therefore, the total dietary fiber content in the fermented drink evaluated was lower than the recommended level. Thus, the fiber present in this product may contribute to positive effects on the consumer's health considering the induced changes in intestinal microbiota and systemic effects on the host's intestinal lumen (SAAD; CRUZ; FARIA, 2011).

The post-acidification during the first seven days of storage was slightly more intense when compared to that of day 21 (Table 2). This finding may be explained by the consumption of lactose resulting in lactic acid production due to lactic bacteria high metabolic activity at $\mathrm{pH} 5.0$ and temperature between 0 and $5{ }^{\circ} \mathrm{C}$ (KEMPKA et al., 2008). Kempka et al. (2008) analyzed the physicochemical characteristics of a fermented milk drink and observed similar behavior when the $\mathrm{pH}$ dropped during storage

Table 1. Centesimal composition and caloric value of the symbiotic fermented drink.

\begin{tabular}{cc}
\hline Assays & Values \\
\hline Humidity $(\mathrm{g} / 100 \mathrm{ml})$ & $82.03 \pm 0.02$ \\
Proteins $(\mathrm{g} / 100 \mathrm{ml})$ & $1.86 \pm 0.01$ \\
Lipids $(\mathrm{g} / 100 \mathrm{ml})$ & $0.50 \pm 0.01$ \\
Fixed mineral residue $(\mathrm{g} / 100 \mathrm{ml})$ & $0.84 \pm 0.00$ \\
Total dietary fiber $(\mathrm{g} / 100 \mathrm{ml})$ & $0.35 \pm 0.02$ \\
Total frutans $(\mathrm{g} / 100 \mathrm{ml})$ & $0.24 \pm 0.03$ \\
Carbohydrates $(\mathrm{g} / 100 \mathrm{ml})$ & $14.42 \pm 0.00$ \\
Caloric value $(\mathrm{Kcal} / 100 \mathrm{ml})$ & $69.62 \pm 0.00$ \\
\hline
\end{tabular}

of 22 days under refrigeration. It was observed that the maximum variation in $\mathrm{pH}$ values was 0.34 on day 21 of storage. This variation was affected by the combinations of microorganisms because the association between Bifidobacterium spp. and S.thermophilus led to lower acetic acid production by probiotic bacteria (FIORENTINI et al., 2011). The lactic acid contents varied during the 21 days of storage increasing over time and during the leavening process. This variation (Table 2) may have occurred as a result of lactic bacteria growth during storage (OLIVEIRA et al., 2006).

The total soluble solid content (Table 2) did not vary in the drink during storage thereby demonstrating homogeneity during all preparation steps, which is the ideal condition for maintaining final product quality. Saad, Cruz and Faria (2011) observed that changes in soluble solids might be related to the package type and advised that the industry should perform migration tests on packages considering that changes may be detected in the product.

The chromaticity coordinates $\mathrm{L}^{*}, \mathrm{a}^{*}$, and $\mathrm{b}^{*}$ were influenced by the storage time; the coordinate and negative values of $\mathrm{a}^{*}$ at time 0 and 21 significantly differed from the values at time 7 and 14 . The $b^{*}$ coordinate showed values that were significantly higher in the first days of storage (Table 3).

Drink color is associated with the presence of pigments in the raw material (yacon) and is therefore, susceptible to seasonal variations. The fermented beverage showed a slightly yellow color with positive values that corroborate the value of coordinate $\mathrm{b}^{\star}$ observed by the CIELAB system $\mathrm{L}^{*}, \mathrm{a}^{*}$, and $\mathrm{b}^{*}$ (Table 3 ). The color parameters showed more pronounced modifications on the surface at day 14 ; the $\mathrm{L}^{*}$ and $\mathrm{b}^{*}$ parameters showed statistically significant differences $(\mathrm{p}<0.05)$. The highest total difference in color $(\Delta \mathrm{E})$ was observed at day 14 , mainly due to the $\mathrm{L}$ value of the sample at this stage of storage. The $b^{*}$ value was the most variable in all treatments.

Exposure to light may affect the color of a product through enzymatic browning because of the presence of phenolic compounds such as chlorogenic acid and the amino acid L-tryptophan (present in yacon). Thus, since the drink evaluated was stored in clear glass containers, it could be susceptible to turn dark due to peroxidase (POD) and polyfenoloxidase (PPO) enzymes (PADILHA et al., 2009). Other factors during processing conditions such as the association of microorganisms, product formulation, storage time, and $\mathrm{pH}$ variation can also affect the color of fermented dairy foods (McCOMAS JUNIOR; GILLILAND, 2003).

Table 2. Physicochemical stability of the symbiotic fermented drink, stored at $6{ }^{\circ} \mathrm{C}$.

\begin{tabular}{ccccc}
\hline \multirow{2}{*}{ Parameters } & \multicolumn{3}{c}{ Time (days) } \\
\cline { 2 - 5 } & 0 & 7 & $4.44 \pm 0.01^{\mathrm{c}}$ & 21 \\
\hline $\mathrm{pH}$ & $4.73 \pm 0.02^{\mathrm{a}}$ & $4.51 \pm 0.02^{\mathrm{b}}$ & $0.38 \pm 0.01^{\mathrm{ab}}$ & $0.01^{\mathrm{c}}$ \\
Lactic acid $(\mathrm{g} / 100 \mathrm{ml})$ & $0.24 \pm 0.01^{\mathrm{c}}$ & $0.36 \pm 0.01^{\mathrm{b}}$ & $14.0 \pm 0.0^{\mathrm{a}}$ & $0.40 \pm 0.01^{\mathrm{a}}$ \\
Soluble solids totals $(\mathrm{g} / 100 \mathrm{ml})$ & $14.0 \pm 0.0^{\mathrm{a}}$ & $14.0 \pm 0.0^{\mathrm{a}}$ & $14.0 \pm 0.0^{\mathrm{a}}$ & \\
\hline
\end{tabular}

Same letters on the same rows indicate statistically similar values $(\mathrm{p}<0.05)$ by the Duncan test. 


\subsection{Microbiological assays}

The symbiotic fermented drink samples did not contain Salmonella ssp. and coliform bacteria thus ensuring the hygienic-sanitary safety of the products produced.

The counts of probiotic bacteria are shown in Table 4. The optimum condition for the growth of these bacteria occurs at a specific $\mathrm{pH}$ range and depends on the species.

Silva, Junqueira and Silveira (2010) observed lower values of lacteous cultures when the total count of viable microorganisms was not performed on individual species.

Lactobacilli developed well at the $\mathrm{pH}$ conditions of the drink because they are acidophiles, they usually grow at $\mathrm{pH}$ between 5.5 and 6.2; however, they can grow at $\mathrm{pH}$ below 5.0 (OLIVEIRA et al., 2006). In addition, some strains of Lactobacillus acidophilus use amino acids and peptides from milk serum, increasing their survival (BURITI et al., 2007; LISERRE; RÉ; FRANGO, 2007; SHAH, 2001).

The bifidobacteria are more sensitive to acid $\mathrm{pH}$, and their ideal substrate are fructooligosaccharides-FOS (THAMER; PENNA, 2005; MENDANHAM et al., 2009).

At 14 days of storage (Table 4), the number of bacteria decreased, mainly the bifids since they are strictly anaerobic and more sensitive to the lactic acid produced by the fermentation process. A similar result was reported by Fiorentini et al. (2011). The recovery of bifidobacteria at day 21 may have resulted from using fructooligosaccharides (FOS) as a nutritional source during the storage period.

According to Cruz et al. (2010), the ideal count of probiotics recommended for fermented dairy beverages is between $10^{6}$ and $10^{7}$ viable cells $/ \mathrm{mL}$. The current Brazilian legislation (BRASIL, 1999) recommends $10^{6} \mathrm{CFU} /$ portion ( $120 \mathrm{~mL}$ of the drink).

The final counts of viable cells in the fermented drink were within the recommended limits for this product after 21 days of storage at refrigeration temperatures. Therefore, the combination of yacon with probiotic cultures in the formulation of dairy products is promising. Current studies have focused on the protection and viability of probiotic cultures during production, storage, and the passage of the product through the gastrointestinal tract. Those studies demonstrate that these cultures can be significantly protected by milk proteins, prebiotic carbohydrates, and microencapsulation using chitosan and sodium alginate, among others (MENDANHAM et al., 2009).

Grosso and Fávaro-Trindade (2004) observed good viability of $L$. acidophilus in milk and acidified milk; these results are similar to those found in the present study at 7 days of storage (Table 4). A similar study was conducted by Buriti and Saad (2007) combining L. acidophilus and the inulin fructan in guava mousse, and they also observed survival of the probiotics up to the first week of storage.

The current Brazilian legislation (BRASIL, 1999) establishes that the minimum viable amount of probiotics must be in the range of $10^{8}$ and $10^{9} \mathrm{CFU} /$ portion. Nevertheless, lower values can be accepted if resistance to gastric acidity and bile salts is proven. According to Cruz et al. (2010), a product with a probiotic count of $10^{9} \mathrm{CFU} / \mathrm{g}$ can maintain its properties with values in the range $10^{4}$ and $10^{6} \mathrm{CFU}$ after tests for resistance to gastric digestion.

Some factors, such as permeability of the package, oxygen level in the products during refrigerated storage, and sensitivity to substances produced by the bacteria can cause loss of viability in probiotic microorganisms in dairy products (OJANSIVU; FERREIRA; IMINEN, 2011; SHAH, 2001). Maintenance of viability of the probiotic bacteria during storage represents a significant technological challenge since fermented foods have a low $\mathrm{pH}$ value, and therefore have shorter shelf life. Storage temperature influences the survival of probiotics, as demonstrated by Conrad et al. (2000), who reported that frozen storage stabilizes the microorganisms compared to refrigerated storage. Buriti and Saad (2007) corroborated this finding in symbiotic mousses stored at freezer temperatures.

Table 3. Colorimetric analyses in the symbiotic fermented drink stored at $6{ }^{\circ} \mathrm{C}$.

\begin{tabular}{ccccc}
\hline \multirow{2}{*}{ Coordinates } & \multicolumn{5}{c}{ Time (days) } \\
\cline { 2 - 5 } & 0 & 7 & $74.75 \pm 0.35^{\mathrm{c}}$ & 21 \\
\hline $\mathrm{L}$ & $88.27 \pm 0.32^{\mathrm{a}}$ & $89.32 \pm 0.1^{\mathrm{a}}$ & $-4.13 \pm 0.03^{\mathrm{c}}$ & $81.26 \pm 0.92^{\mathrm{b}}$ \\
$\mathrm{a}^{*}$ & $-4.45 \pm 0.07^{\mathrm{b}}$ & $-4.22 \pm 0.04^{\mathrm{c}}$ & $7.26 \pm 0.15^{\mathrm{c}}$ & $-4.63 \pm 0.07^{\mathrm{a}}$ \\
$\mathrm{b}^{*}$ & $13.55 \pm 0.07^{\mathrm{a}}$ & $12.27 \pm 0.95^{\mathrm{a}}$ & 14.91 & $9.22 \pm 0.11^{\mathrm{b}}$ \\
$\Delta \mathrm{E}^{*}$ & - & 1.67 & 8.24 & 8. \\
\hline
\end{tabular}

Same letters on the same rows indicate statistically similar values $(\mathrm{p}<0.05)$ by the Duncan test.

Table 4. Growth of Lactobacillus acidophilus and Bifidobacteria bifidum in the symbiotic fermented drink stored at $6^{\circ} \mathrm{C}$.

\begin{tabular}{ccccc}
\hline Microorganisms & \multicolumn{3}{c}{ Time (days) } \\
\cline { 2 - 5 } & 0 & 7 & 14 & 21 \\
\hline Lactobacillus acidophilus $(\mathrm{CFU} / \mathrm{mL})$ & $1.6 \times 10^{9}$ & $2.1 \times 10^{9}$ & $0.2 \times 10^{7}$ & $2.36 \times 10^{9}$ \\
Bifidobacterium bifidum $(\mathrm{CFU} / \mathrm{mL})$ & $2.0 \times 10^{9}$ & $4.2 \times 10^{8}$ & $\mathrm{NI}^{\mathrm{a}}$ & $2.64 \times 10^{9}$ \\
\hline
\end{tabular}

(a) Non-identfied. 
According to Saad, Cruz and Faria (2011), lactobacilli can resist to acid, which is attributed to the constant presence of a gradient between the extracellular and cytoplasmic pHs. However, when the cytoplasmic $\mathrm{pH}$ reaches its limit, the cellular functions are inhibited and the cell dies. The drink's $\mathrm{pH}$ varied from 4.51 to 4.39 (Table 2) after the $7^{\text {th }}$ day of storage, which might have contributed to reducing the viability of $L$. acidophilus (Table 5). Moreover, after 30 minutes of the in vitro digestion process, a decrease in the survival of probiotic of $10^{6} \mathrm{CFU} / \mathrm{ml}$ at all days of storage was observed.

This result can be attributed to the gastric step in the methodology used, which is vital to ensure the viability of the microorganism until the end of the assay.

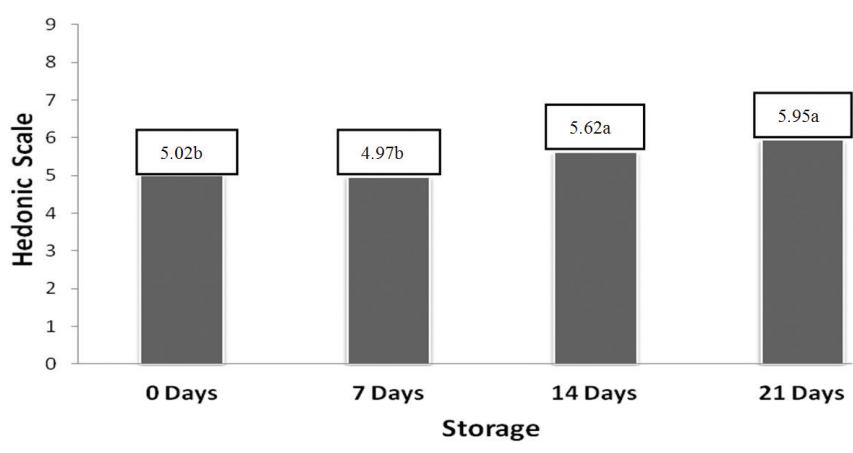

Figure 1. The acceptance of the symbiotic fermented drink, stored at $6{ }^{\circ} \mathrm{C}$. Same letters on different days indicate statistically similar values $(\mathrm{p}<0.05)$ by the Duncan test.

\subsection{Sensory analysis and purchase intention}

The sensory analysis indicated that time of storage and $\mathrm{pH}$ during the refrigerated storage caused significant changes in acceptability. The average scores attributed using the 9-point hedonic were 'like slightly' and 'dislike slightly' (4.97 and 5.95) (Figure 1).

The acidification of the drink resulted in higher acceptability at 21 days of storage with $65.9 \%$ of the responses positioned between 'neither like nor dislike' and 'like slightly'. According to Thamer and Penna (2005), acid production defines the quality characteristics and shelf life of the product; a probiotic fermented food should reach up to $\mathrm{pH} 4.6$, which is close to that obtained in this study, to ensure light flavor and avoid adverse effects of low $\mathrm{pH}$ on probiotic bacteria. Furthermore, acidophilus products are appreciated by a limited group of consumers, which could have contributed to the acceptability of the studied drink (Figure 2).

The purchase intention answer "maybe would buy" had the highest percentage in all steps of the evaluation (Figure 2). The percentage of "would buy" answers increased at days 14 and 21; sensory evaluation demonstrated a higher acceptance of the drink at day 21 of storage.

Studies on consumer's attitudes toward probiotic products indicate the growing interest in the consumption of functional foods that benefit health (VIANA et al., 2008). However, there is a consensus on the lack of knowledge about the functionality and benefits of these foods in the population, regardless of gender, age, and educational and economical background (VIANA et al., 2008; CRUZ et al., 2011).

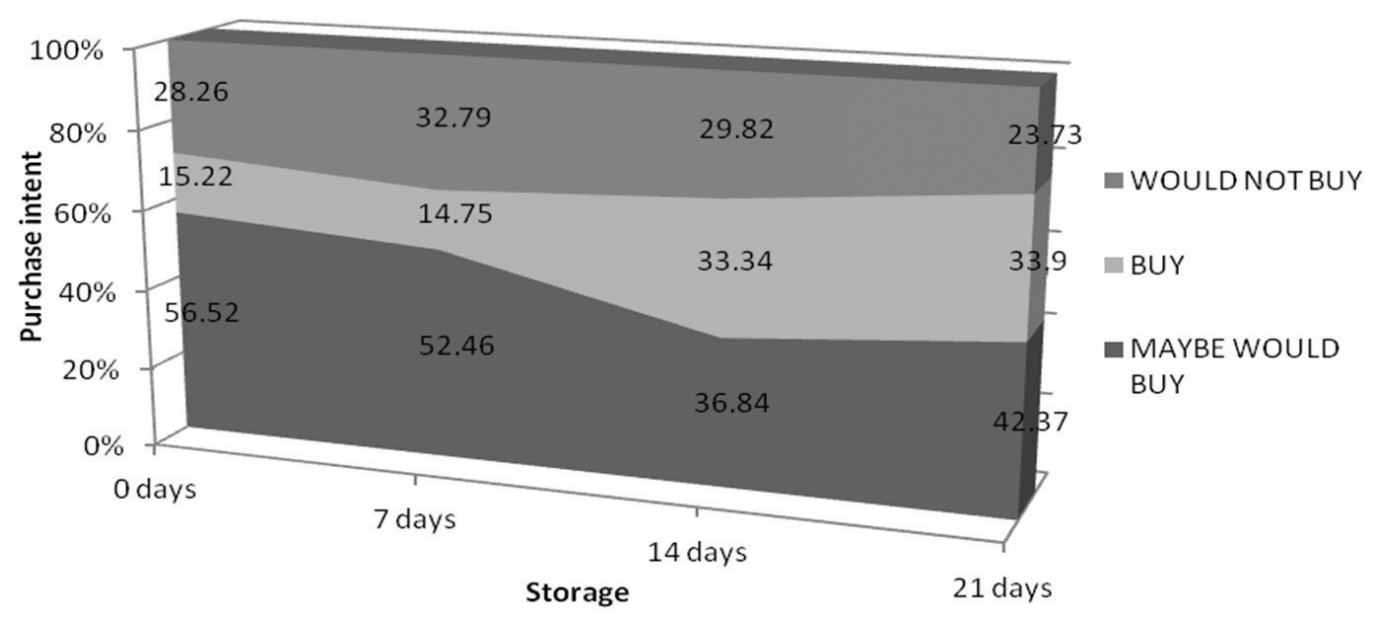

Figur 2. Purchase intention of the symbiotic fermented drink stored at $6{ }^{\circ} \mathrm{C}$.

Table 5. In vitro viability of L. acidophilus $(\mathrm{CFU} / \mathrm{mL})$ in the symbiotic fermented drink stored at $6{ }^{\circ} \mathrm{C}$.

\begin{tabular}{|c|c|c|c|c|}
\hline \multirow{2}{*}{ Digestion time } & \multicolumn{4}{|c|}{ Time (days) } \\
\hline & 0 & 7 & 14 & 21 \\
\hline 30 minutes & $9.0 \times 10^{6}$ & $1.47 \times 10^{8}$ & $2.8 \times 10^{8}$ & $1.5 \times 10^{3}$ \\
\hline 1 hour & $3.2 \times 10^{2}$ & $3.0 \times 10^{4}$ & $2.0 \times 10^{2}$ & $\mathrm{NI}^{\mathrm{a}}$ \\
\hline 2 hours & $4.4 \times 10^{3}$ & $2.5 \times 10^{2}$ & $1.1 \times 10^{2}$ & $\mathrm{NI}^{\mathrm{a}}$ \\
\hline 4 hours & $1.7 \times 10^{3}$ & $1.0 \times 10^{3}$ & $0.4 \times 10^{2}$ & $\mathrm{NI}^{\mathrm{a}}$ \\
\hline 6 hours & $4.5 \times 10^{3}$ & $1.0 \times 10^{6}$ & $1.3 \times 10^{2}$ & $\mathrm{NI}^{\mathrm{a}}$ \\
\hline
\end{tabular}

(a) Non-identfied. 


\section{Conclusions}

The results of this study demonstrated that the symbiotic drink was characterized as a skimmed fermented dairy drink, according to the Brazilian legislation.

The presence of fructooligosaccharides (FOS) from yacon, L. acidophilus $L A-5$ and B.bifidum BB-12 in the drink resulted in satisfactory counts of probiotics up to 21 days of storage, period of time when it obtained the best responses in the sensory evaluation. However, the Lactobacillus acidophilus levels of resistance to gastric acids and bile salts were satisfactory only after to the $7^{\text {th }}$ day of storage.

The consumers' scores regarding purchase intention were positive, suggest and encourage future production and commercialization of this product as long as the probiotic resists to the gastric conditions during all storage period.

\section{References}

ANTUNES, A. E. C. et al. Desenvolvimento de buttermilk probiótico. Food Science and Technology, v. 27, n. 1, p. 83-90, 2007.

ASSOCIATION OF OFFICIAL ANALYTICAL CHEMISTS - AOAC. Official methods of analysis of the association analytical chemists. 18. ed. Maryland: AOAC, 2002.

BRASIL. Agência Nacional de Vigilância Sanitária. Resolução nº 18, de 30 de abril de 1999. Aprova o Regulamento Técnico que estabelece as Diretrizes Básicas para Análise e Comprovação de Propriedades Funcionais e ou de Saúde Alegadas em Rotulagem de Alimentos. Diário Oficial da União, Brasília, 3 de maio de 1999. Seção 1, p. 9.

BRASIL. Ministério da Agricultura Pecuária e Abastecimento. Resolução n 5, de 13 de novembro de 2000. Padrões de Identidade e Qualidade (PIQ) de Leites Fermentados. Diário Oficial da República Federativa do Brasil, Brasília, 27 de novembro de 2000. Seção 1, p. 9.

BRASIL. Ministério da Agricultura, Pecuária e Abastecimento. Instrução Normativa n.16, 23 de agosto de 2005. Regulamento técnico de identidade e qualidade de bebida láctea. Diário Oficial da República Federativa do Brasil, Brasília, 24 de agosto de 2005. Seção 1, p. 7.

BÜRGER, K. P. et al. Caracteristicas microbiológicas de leite integral e bebida láctea processados por UAT (Ultra Alta Temperatura) ao longo do período de validade. Arquivos do Instituto Biológico, v. 78, n. 1, p. 129-136, 2011.

BURITI, F. C. A.; SAAD, S. M. I. Bactérias do grupo Lactobacillus casi: caracterização, viabilidade como probióticos em alimentos e sua importância para a saúde humana. Archivos Latinoamericanos de Nutricion, v. 57, n. 4, p. 373-380, 2007. PMid:18524322.

BURITI, F. C. A. et al. Synbiotic potential of fresh cream cheese supplemented with inulin and Lactobacillus paracasei in coculture with Steptococcus thermophilus. Food chemistry, v. 104 , n. 4 , p. $1605-1610$, 2007. http://dx.doi.org/10.1016/j. foodchem.2007.03.001

CARDARELLI, H. R. et al. Inulin and oligofructose improve sensory quality and increase the probiotic viable count in potentially symbiotic petit-suisse cheese. Food Science and Technology, v. 41, n. 6, p. 1037-1046, 2008.

COMMISSION INTERNATIONALE DE I ECLAIRAGE. Colorimetry. 2. ed. Vienna: CIE Publication, 2004.
CONRAD, P. B. et al. Stabilization and preservation of Lactobacillus acidophilus in saccharide matrices. Cryobiology, v. 41, n. 1, p. 17-24, 2000. http://dx.doi.org/10.1111/j.1365-2621.2007.01596.x

CRUZ, A. G. et al. High pressure processing and pulsed electric fields: potential use in probiotic dairy foods processing. Trends in food Science \& Technology, v. 21, n. 10, p. 483-493, 2010. http://dx.doi. org/10.1016/j.tifs.2010.07.006

CRUZ, A. G. et al. Consumer acceptability and purchase intent of probiotic yoghurt with added glucose oxidase using sensometrics, artificial neural networks and logistic regression. International Journal of Dairy Technology, v. 64, p. 549-556, 2011.

FIGUEIROA-GONZALEZ, I.; CRUZ-GUERRERO, A.; QUIJANO, G. The benefits of probiotics on human health. Journal of Microbial and Biochemical Technology, v. 22, n. 003, p. 1948-5948, 2011.

FIORENTINI, A. M. et al. The influence of different combinations of probiotic bacteria and fermentation temperatures on the microbiological and physicochemical characteristics of fermented lactic beverages containing soybean hydrosoluble extract during refrigerated storage. Food Science and Technology, v. 31, n. 3, p. 597-607, 2011.

GRAEFE, S. et al. Effects of post-harvest treatments on the carboydrate composition of yacon roots in the Peruvian Andes. Field Crops Research, v. 86, n. 3, p. 157-165, 2004.

GROSSO, C. R. F.; FÁVARO-TRINDADE, C. S. Stability of free and immobilized Lactobacillus acidophilus and Bifidobacterium lactis in acidified milk and of immobilized B. lactis in yoghurt. Brazilian Journal of Microbiology, v. 35, n. 1-2, p. 151-156, 2004. PMid:11017757. http://dx.doi.org/10.1006/cryo.2000.2260

HAUG, A.; HOSTMARK, A. T.; HARSTAD, O. M. Bovine Milk in human nutrition - a review. Lipids in Health and Disease, v. 6, n. 25, p. 1-16, 2007.

INTERNATIONAL DAIRY FEDERATION. Fermented and non-fermented milk products detection and enumeration of Lactobacillus acidophilus - culture media. Brussels: International Dairy Federation, 1995.36 p. (Bulletin of the IDF, 306). http://dx.doi. org/10.1080/08905430701191064

KEMPKA, A. P. et al. Formulação de bebida láctea fermentada sabor pêssego utilizando substratos alternativos e cultura probiótica. Food Science \& Technology, v. 28, p. 170-177, 2008.

LISERRE, A. M.; RÉ, M. I.; FRANGO, B. D. C. M. Microencapsulation of Bifidobacterium animals subsp.lactis in modified alginate-chitosan beads and evalution of survival in simulated gastrointestinal conditions. Food Biotechnology, v. 21, n. 1, p. 1-16, 2007.

McCOMAS JUNIOR, K. A.; GILLILAND, S. E. Growth of probiotic and traditional yogurt cultures in milk supplemented with whey protein hydrolysate. Journal of Food Science, v. 68, n. 6, p. 2090-2095, 2003.

MENDANHAM, D. V. et al. Microencapsulation of casein hydrolysate by complex coacervation with SPI/pectin. Food Research International, v. 42, n. 8, p. 1099-1104, 2009. http://dx.doi. org/10.1590/S1517-83822004000100025

OJANSIVU, I.; FERREIRA, C. L.; IMINEN, S. S. Yacon, a new source of prebiotic oligosaccharides with a history of use. Trends in food Science and Technology, v. 22, n. 1, p. 40-46, 2011. http://dx.doi. org/10.1016/j.tifs.2010.11.005

OLIVEIRA, V. M. et al. Sensorial analysis of fermented dairy beverage with different concentrations of cheese whey enriched with iron. Revista Brasileira de Ciência Veterinaria, v. 13, n. 2, p. 67-70, 2006. http://dx.doi.org/10.1111/j.1365-2621.2003.tb07024.x

PADILHA, V. M. et al. Drying evaluation time and yacon (Smallanthus sonchifolius) enzymatic activity inhibition under chemical 
treatment. Ciência Rural, v. 29, n. 7, p. 2178-2184, 2009. http:// dx.doi.org/10.1590/S0103-84782009005000142

QUEMENER, B.; THIBAULT, J. F.; COUSSEMENT, P. Determination of inulin and oligofructose in food products and integration in the AOAC method for measurement of total dietary fibre. Lebensmittel Wissenschaft und Technologie, v. 27, n. 2, p. 125-132, 1994.

QUEMENER, B.; THIBAULT, J. F.; COUSSEMENT, P. Integration of inulin determination in the AOAC method for measurement of total dietary fiber. International Journal of Biological Macromolecules, v. 21, n. 1-2, p. 175-178, 1997. http://dx.doi.org/10.1016/S01418130(97)00058-5

SAAD, S. M.; CRUZ, A. G.; FARIA, J. A. F. Probióticos e Prebióticos em Alimentos: fundamentos e aplicações tecnológicas. São Paulo: Varela, 2011.

SHAH, N. P. Functional foods from probiotics and prebiotics. Food Technology, v. 55, n. 11, p. 46-53, 2001. http://dx.doi.org/10.1590/ S1516-93322005000300013

SILVA, N.; JUNQUEIRA, V. C. A.; SILVEIRA, N. F. A. Manual de métodos de análise microbiológica de alimentos. 4. ed. São Paulo: Varela, 2010.
STATSOFT. STATISTICA: data analysis software systems. Version 6.0. Tulsa: StatSoft, 2004. 1 CD-ROM.

SWANSON, K. S. et al. Frutooligosaccharides and Lactobacillus acidophilus modify gut microbial populations, total tract nutrient digestibilities and fecal protein catabolite concentrations in healthy adult dogs. The Journal of Nutrition, v. 132, n. 12, p. 3721-3731, 2002. PMid:12468613.

THAMER, K. G.; PENNA, A. L. B. Efeito do teor de soro, açúcar e de frutooligossacarídeos sobre a população de bactérias láticas probióticas em bebidas fermentadas. Revista Brasileira de Ciências Farmaceuticas, v. 41, n. 3, p. 393-400, 2005. http://dx.doi. org/10.1016/j.foodres.2009.05.007

THAMER, K. G.; PENNA, A. L. B. Caracterização de bebidas lácteas funcionais fermentadas por probióticos e acrescidas de prebiótico. Food Science and Technology, v. 26, n. 3, p. 589-595, 2006. http:// dx.doi.org/10.1016/j.fcr.2003.08.003

VIANA, J. V. et al. Probiotic foods: consumer perception and attitudes. International Food Science and Technology, v. 43, n. 9, p. 1577 1580, 2008.

ZAVAREZE, E. R.; MORAES, K. S.; SALAS-MELLADO, M. L. M. Technological and sensory quality of cakes produced with milk whey. Food Science and Technology, v. 30, n. 1, p. 100-105, 2010. 